Ann. Zootech., 1980, 29, no h. s., 251-259.

\title{
The influence of protein levels on growth rate and feed efficiency
}

\author{
T. COBIĆ, S. BAČVANSKI and Sofija VUČETIĆ \\ Faculty of Agriculture, \\ Livestock Research Institute, Novi Sad (Yugoslavia).
}

\begin{abstract}
With mixed diets crude protein (CP) levels in the dry matter (DM) higher than 13.5 per cent in first fattening period (up to $250 \mathrm{~kg}), 12.8$ per cent in the second $(250-350 \mathrm{~kg}$ ) and 12.0 per cent in the final fattening period $(350 \mathrm{~kg}$ to slaughter) did not significantly affect the performance of bulls gaining about $1200 \mathrm{~g} / \mathrm{day}$. By using high concentrate (HC) diets, CP levels lower than 14.5 per cent in the first period, 13.3 per cent in the second and 12.2 per cent in the final period of fattening significantly affected the LWG of about $1250 \mathrm{~g}$, but there was no decrease in feed efficiency using some lower CP levels in DM of the ration (12.2 per cent in the first fattening period, 11.1 per cent in the second and 10.0 per cent in the final period). However for the LWG higher than $1250 \mathrm{~g}$ it would be necessary to raise the $C P$ level by one percentage unit. Crude protein levels lower than 10 per cent detrimentally affected the performance of young bulls.
\end{abstract}

\section{Résumé}

\section{Influence du niveau des apports azotés sur la vitesse de croissance et l'efficacité alimentaire}

Avec des rations de fourrages et de concentrés, une augmentation de la teneur en matières azotées totales dans la matière sèche au-delà de 13,5 p. 100 en début de période d'engraissement (jusqu'à $250 \mathrm{~kg}$ ), 12,7 p. 100 en milieu de période $(250-350 \mathrm{~kg}$ ) et $12 \mathrm{p} .100$ en fin de période ( $350 \mathrm{~kg}$ - abattage) n'a pas modifié significativement les performances des taurillons ayant un croît de $1200 \mathrm{~g}$ /jour. Avec des rations riches en concentrés, une diminution de la teneur en matières azotées totales en-dessous de 14,5 p. 100 en première période, 13,2 p. 100 en seconde période et 12,2 p. 100 en période finale a modifié significativement le gain de poids autour de $1250 \mathrm{~g} / \mathrm{j}$, mais l'efficacité alimentaire n'a pas diminué sous l'effet de niveaux azotés faibles $(12,2$ p. 100 en première période, 11,1 p. 100 en seconde et 10 p. 100 en période finale). Cependant, pour atteindre des gains journaliers supérieurs à $1250 \mathrm{~g}$ il faudrait élever le pourcentage de matières azotées totales de 1 point.

Avec des rations ayant une teneur en matières azotées inférieure à 10 p. 100, les performances des taurillons ont été nettement affectées. 


\section{Introduction}

During the last several years considerable attention has been devoted to the possibility of decreasing protein levels in the rations for fattening cattle. On the basis of extensive research some new feeding standards have been developed (MAFF, 1977 ; NRC, 1970 ; Jentsch et al., 1975 ; Sorensen and KousgaARd, 1977). However, there is a great variety of breeds and feeding practices used in different parts of the world and therefore the results do not always agree with respect to protein level applied in rations for fattening cattle. In Europe the majority of experiments was conducted with bulls while in the UK and USA they were carried out with steers. However, currently there are more experiments with bulls in these countries too.

This paper deals with some work conducted with the aim of decreasing the protein levels of the rations for fattening young bulls.

\section{Different protein quantities in fattening bulls on mixed rations}

\section{Experimental}

The experiment was conducted with four groups of nine bulls each (7 Dutch Friesian breed and 2 Simmental $x$ Dutch Friesian crosses). The animals were tied and group fed twice a day. Concentrates were given at the rate of $1.75 \mathrm{~kg} / 100 \mathrm{~kg}$ liveweight of bulls, lucerne hay $1 \mathrm{~kg}$ and maize silage $7-12$ $\mathrm{kg} / \mathrm{head} /$ day. The ratio of concentrates to roughages was about $60: 40$. Fattening period was divided into three periods according to liveweights (LW) of animals (up to $250 \mathrm{~kg}, 250-350 \mathrm{~kg}$ and $350 \mathrm{~kg}$ to slaughter weights). The feeding scheme anticipated four protein levels in relation to requirements $(70$, 80,90 and 100 per cent for the respective groups, I - IV). Therefore in the first period (195 - $250 \mathrm{~kg})$ the amount of DCP per one starch unit (SU) ranged from $140-200 \mathrm{~g}$, in the second period $(250-350 \mathrm{~kg})$ from $126-180 \mathrm{~g}$, and in the third period ( $350-435 \mathrm{~kg}$ ) from 111 to $160 \mathrm{~kg}$. In each period four concentrate mixtures were used, based largely on ground maize, $89-63$ per cent, and sunflower oil meal, 8 - 34 per cent, plus 3 per cent minerals and vitamins.

Digestibility trials were conducted on three representative animals from each group for all three periods and the nutritive value of the rations was computed using the digestibility coefficients obtained. Inedible hemp residues were used for bedding.

\section{Results and discussion}

The results are presented in Tables 1 and 2 .

The higher protein level of the rations increase the liveweight gains (LWG), but the differences were small and insignificant. The same applied with the dressing percentage.

GiaRdini et al. $(1976,1976 a)$ compared different protein levels, from 8 15 per cent in the DM and found significant differences in LWG between the level of 8 per cent and higher levels of protein. However, using the beef animals 
TABLE 1

PERFORMANCE OF BULLS FATTENED ON MIXED DIETS BASED ON MAIZE SILAGE AND GROUND MAIZE WITH DIFFERENT PROTEIN LEVEL

\begin{tabular}{l|c|c|c|c}
\hline Group & I & II & III & IV \\
\hline CP in the DM & $13.5-12.0$ & $14.3-12.1$ & $15.7-13.4$ & $16.3-14.3$ \\
\hline Number of animals & 9 & 9 & 9 & 9 \\
Initial weight, kg & 195.89 & 194.89 & 194.89 & 195.22 \\
Final weight, kg & 432.33 & 436.00 & 434.27 & 438.66 \\
Experimental days & 200 & 200 & 200 & 200 \\
Average daily LWG, g & 1183 & 1207 & 1198 & 1218 \\
Whole fattening period & 1088 & 1092 & 1099 & 11.42 \\
$195-250 \mathrm{~kg}$ & 1253 & 1243 & 1254 & 1263 \\
$150-350 \mathrm{~kg}$ & 1201 & 1267 & 1234 & 1245 \\
$350-435 \mathrm{~kg}$ & 58.7 & 58.4 & 59.1 & 58.0 \\
Dressing percentage & & & & \\
\hline
\end{tabular}

differences were not significant. In the studies at ITCF $(1977,1978)$ with young bulls fed on mixed rations containing CP levels from 10.9 to 15.1 per cent no differences were found with respect to $\mathrm{LWG}$, since there was a slight improvement due to the increased protein level. MARTIN et al., (1979) reported that bulls fed on 11.1 - 15.9 per cent $\mathrm{CP}$ in the DM in mixed rations did not significantly differ in LWG for the whole fattening period although they did differ during the first 56 days of experiment. On the basis of these data it seems that the protein level in the DM of the ration for fattening of young bulls could not be decreased below 11 per cent, although MARTIN et al. (1978) suggest that continuous levels of dietary protein higher than 11 per cent cannot be justified for beef cattle. However, it must be emphasised that the majority of American experiments were conducted with beef cattle of higher LW at the beginning of fattening and therefore they could not be applied directly to European conditions. Lower levels than 11 per cent $\mathrm{CP}$ produced lower gains in all the experiments reported.

Daily DM intake (Table 2) depended on the weight of animals, and the variations in the daily amounts of DM consumed were quite small. Intake of digestible crude protein (DCP) was somewhat lower than anticipated, ranging from 89.9 to 99.4 per cent of the expected level. Therefore the ratio of DCP to SU was also lower, ranging from 139 to $184 \mathrm{~g}$ in the first period, $120-170 \mathrm{~g}$ in the second, and $106-159 \mathrm{~g}$ in the third period of fattening, which corresponds to 13.5 - 16.3 per cent $\mathrm{CP}$ in the DM in the first period $(195-250 \mathrm{~kg}) 12.8-$ 15.7 per cent $\mathrm{CP}$ in the second period $(250-350 \mathrm{~kg})$ and $12-14.4$ per cent $\mathrm{CP}$ in the final period of fattening $(350-436 \mathrm{~kg})$. The average apparent digestibility of protein ranged from 55.05 to 68.93 per cent, increasing with the protein level of the ration, irrespective of the fattening period. 
TABLE 2

INTAKE AND CONVERSION OF FEEDS AND NUTRIENTS IN YOUNG FATTENING BULLS FED ON MIXED RATIONS*

\begin{tabular}{|c|c|c|c|c|}
\hline Group & I & II & III & IV \\
\hline$C P$ in the $\mathrm{DM}$ & $13.5-12.0$ & $14.3-12.1$ & $15.7-13.4$ & $16.3-14.3$ \\
\hline \multicolumn{5}{|l|}{ Daily intake, $\mathrm{kg}$} \\
\hline \multicolumn{5}{|l|}{$\mathrm{DM}, \mathrm{kg} / 100 \mathrm{~kg} \mathrm{LW}$} \\
\hline $195-250 \mathrm{~kg}$ & 2.34 & 2.35 & 2.33 & 2.33 \\
\hline $250-350 \mathrm{~kg}$ & 2.16 & 2.18 & 2.16 & 2.15 \\
\hline $350-435 \mathrm{~kg}$ & 1.92 & 1.92 & 1.92 & 1.90 \\
\hline \multicolumn{5}{|l|}{ DCP } \\
\hline Whole exp. period & 0.485 & 0.551 & 0.606 & 0.670 \\
\hline $195-250 \mathrm{~kg}$ & 0.466 & 0.505 & 0.538 & 0.581 \\
\hline $250-350 \mathrm{~kg}$ & 0.483 & 0.539 & 0.610 & 0.678 \\
\hline $350-435 \mathrm{~kg}$ & 0.488 & 0.584 & 0.637 & 0.737 \\
\hline \multicolumn{5}{|l|}{ SU } \\
\hline Whole exp. period & 4.02 & 4.04 & 3.98 & 3.96 \\
\hline $195-250 \mathrm{~kg}$ & 3.36 & 3.29 & 3.20 & 3.15 \\
\hline $250-350 \mathrm{~kg}$ & 3.99 & 4.06 & 3.93 & 3.99 \\
\hline $350-435 \mathrm{~kg}$ & 4.58 & 4.71 & 4.67 & 4.62 \\
\hline \multicolumn{5}{|c|}{ Daily intake, $\mathrm{g} / \mathrm{kg} \mathrm{w}^{0.75}$} \\
\hline \multicolumn{5}{|l|}{ Whole exp. period } \\
\hline $\mathrm{DCP}$ & 8.6 & 9.7 & 10.7 & 11.7 \\
\hline $\mathrm{SU}$ & 71.3 & 71.2 & 70.3 & 69.4 \\
\hline \multicolumn{5}{|l|}{ Feed conversion, $\mathrm{kg}$} \\
\hline \multicolumn{5}{|l|}{$\mathrm{DCP}$} \\
\hline Whole exp. period & 0.410 & 0.456 & 0.506 & 0.550 \\
\hline $195-250 \mathrm{~kg}$ & 0.428 & 0.462 & 0.489 & 0.509 \\
\hline $250-350 \mathrm{~kg}$ & 0.385 & 0.432 & 0.486 & 0.537 \\
\hline $350-435 \mathrm{~kg}$ & 0.406 & 0.461 & 0.516 & 0.592 \\
\hline \multicolumn{5}{|l|}{ sU } \\
\hline Whole exp. period & 3.40 & 3.35 & 3.32 & 3.25 \\
\hline $195-250 \mathrm{~kg}$ & 3.09 & 3.01 & 2.91 & 2.76 \\
\hline $250-350 \mathrm{~kg}$ & 3.18 & 3.26 & 3.13 & 3.16 \\
\hline $350-435 \mathrm{~kg}$ & 3.82 & 3.72 & 3.78 & 3.71 \\
\hline
\end{tabular}

* Concentrate to roughage ratio approximately $60: 40$. 
Efficiency of DCP decreased by increasing the CP level of the rations, by 11.23 per cent and 34 per cent in groups II, III and IV as related to group I, which indicates a possibility of saving protein, especially in the fattening period after $250 \mathrm{~kg}$ of $\mathrm{LW}$.

Our dota are in agreement with those of ITCF $(1977,1978)$ and MARTIN et al., (1978), showing that DM intake and feed conversion were not affected by the level of DCP in the DM of the rations, while GiardinI et al., (1976, 1976a) found a decrease of DM intake and less efficient conversion of feeds at the level of 8 per cent CP in comparison with higher protein levels.

On the basis of these data, satisfactory results in fattening of young bulls on mixed rations have been obtained by providing CP content of DM of 13.5 per cent at the beginning, 12.8 per cent in the middle, and 12 per cent at the end of the fattening period. In this experiment it corresponds to about $8.7,7.4$ and 6.6 per cent DCP in DM. These figures are somewhat higher than those recommended by NRC (1970) ranging between 11.1 and 12.8 per cent of total protein for steers. Our DCP figures concerning protein intake in groups I and II are lower, while those of groups III and IV are higher for the respective LW, than those recommended by JENTSCH et al. (1975) for bulls gaining $1200 \mathrm{~g} /$ day.

\section{Different protein quantities in fattening of bulls on high concentrate rations}

\section{Experimental}

An investigation was conducted with 40 young bulls of the Dutch Friesian breed divided into four groups. The animals were tied and fed individually on HC rations based largely on ground maize, 57.5 - 76.0 per cent, dry sugar beet pulp, 15 per cent, sunflower oil meal $1-16.5$ per cent and dehydrated lucerne meal 5 per cent, with 3 per cent added minerals and vitamins. In the lowest protein group, corn and cob meal was used at the rate of 32 and 92 per cent instead of ground maize. The animals were fed ad libitum and watered from automatic water bowls. In the digestibility studies the same method was applied as described in the previous experiment.

\section{Results and discussion}

The results obtained are presented in tables 3 and 4 .

The average daily liveweight gains in the first period of fattening ranged from $1,006 \mathrm{~g}$ in the animals of group $\mathrm{I}$ to $1,370 \mathrm{~g}$ in group IV. Liveweight gain of animals fed on rations with 10.0 per cent $C P$ in the DM was significantly lower than with 14.5 and 16.6 per cent $\mathrm{CP}$, while the gain of bulls fed on rations containing 12.2 per cent CP differed significantly from those fed on rations with 16.6 per cent. Although the same tendency persisted throughout the other two periods, the differences between treatments were not significant. However, the LWG achieved in the first period of fattening affected the differences for the whole experimental period (from $136-450 \mathrm{~kg}$ ) since the $\mathrm{LWG}$ were significantly lower in animals of group $\mathrm{I}$, than in those of groups III and IV, and in animals of group II compared with those of group IV. Hence, a CP content lower than 10 per cent in the DM significantly affected the LWG. Our results (OBRAČEvić et al., 1970, 1971, 1975) with higher CP levels in $\mathrm{HC}$ rations, ranging from 11.6 to 20.2 per cent $\mathrm{CP}$ in the DM, showed no 
TABLE 3

PERFORMANCE OF BULLS FED ON HIGH CONCENTRATE RATIONS WITH DIFFERENT PROTEIN LEVEL

\begin{tabular}{|c|c|c|c|c|}
\hline Group & $I$ & II & III & IV \\
\hline $\mathrm{CP}$ in the $\mathrm{DM}$ & $10.0-7.8$ & $12.2-10.0$ & $14 \cdot 5-12.2$ & $16.6-14.5$ \\
\hline Number of animals & 10 & 10 & 10 & 10 \\
\hline Initial weight, $\mathrm{kg}$ & $135: 8$ & 136.5 & 136.2 & 136.0 \\
\hline Final weight, $\mathrm{kg}$ & 448.2 & 448.3 & 449.3 & 445.9 \\
\hline Experimental days & 288.3 & 271.0 & 251.1 & 238.0 \\
\hline Average daily IWG, g & & & & \\
\hline Whole fattening period & $1084 \pm 35^{a}$ & $1150 \pm 34 \mathrm{ab}$ & $1247 \pm 45^{\mathrm{bc}}$ & $1302 \pm 32^{\mathrm{C}}$ \\
\hline $136-250 \mathrm{~kg}$ & $1006 \pm 67^{a}$ & $1091 \pm 31^{a b}$ & $1215 \pm 7,5,6 \mathrm{c}$ & $1370 \pm 70^{\mathrm{C}}$ \\
\hline $250-350 \mathrm{~kg}$ & $1178 \pm 38$ & $1192 \pm 66$ & $1278 \pm 66$ & $1277 \pm 34$ \\
\hline $350-450 \mathrm{~kg}$ & $1086 \pm 73$ & $1187 \pm 46$ & $1256 \pm 57$ & $1251 \pm 49$ \\
\hline Dressing percentage & 58.38 & 58.58 & 58.71 & 59.10 \\
\hline
\end{tabular}

a, b, c Means with different superscripts are different.

response in LWG. Similar results were obtained by BUYSSE (1969) by applying 13-17 per cent CP and ITCF (1976a, 1977a) using rations with 13.2-15.9 per cent CP. However, WiLliams et al. (1975) found no significant difference in LWG by decreasing the CP level from 14 to 12 per cent versus 12 to 10 per cent. EDWARDS and SwaN (1976) compared two $\mathrm{HC}$ rations in fattening bulls and recorded a significant decrease of LWG by decreasing of CP level from 15 to 10 per cent as compared to that from 15 to 14 per cent. At the ITCF (1976) significantly lower gains were recorded by using rations with 12.1-10.3 per cent $\mathrm{CP}$ as compared to those with higher $\mathrm{CP}$ levels. KAY (1977) obtained considerably lower gains by reduction of protein level from 14.5 to 9.4 per cent or from 12.0 to 9.4 per cent after $250 \mathrm{~kg} \mathrm{LW}$ of animals. DE BoER and HAMM (1977) concluded that daily gain was unfavourably affected if the amount of protein was lower than $6.5 \mathrm{~g}$ of DCP $/ \mathrm{kg} \mathrm{W}^{0.75}$, but the higher protein levels did not affect the daily gains. Our data are in agreement with these, since the amount of DCP $/ \mathrm{kg} \mathrm{W}^{\mathbf{0 . 7 5}}$ ranged from 5.2 to $3.8 \mathrm{~g}$ in group I, 6.6 to $5.2 \mathrm{~g}$ in group II, 8.8 to $7.4 \mathrm{~g}$ in group III and 11.2 to $9.1 \mathrm{~g}$ in group IV, respectively.

Differences in dressing percentage are small and inconclusive as regards the effect of different treatments.

Dry matter intake (table 4) was lower on the low protein ration (group I) in the first and third fattening period. The corresponding figures per $\mathrm{W}^{\mathbf{0 . 7 5}}$ ranged mostly between 80 and $90 \mathrm{~g}$, while only in the last period of fattening the bulls of groups I and II, fed on low protein rations, consumed less than $80 \mathrm{~g} \mathrm{DM} / \mathrm{kg} \mathrm{W}^{\mathbf{0 . 7 5}}$. Data on digestibility of protein ranged between 62.1 per cent, in animals fed on rations with 7.8 per cent $C P$ in the $D M$, to 76.6 per cent in those fed on rations containing 16.6 per cent $\mathrm{CP}$, which confirmed our earlier observation that the apparent digestibility of protein increased with increasing protein level (OBRAČEVIĆ 
TABLE 4

INTAKE AND CONVERSION OF FEEDS AND NUTRIENTS IN YOUNG FATTENING BULLS FED ON HIGH CONCENTRATE RATIONS

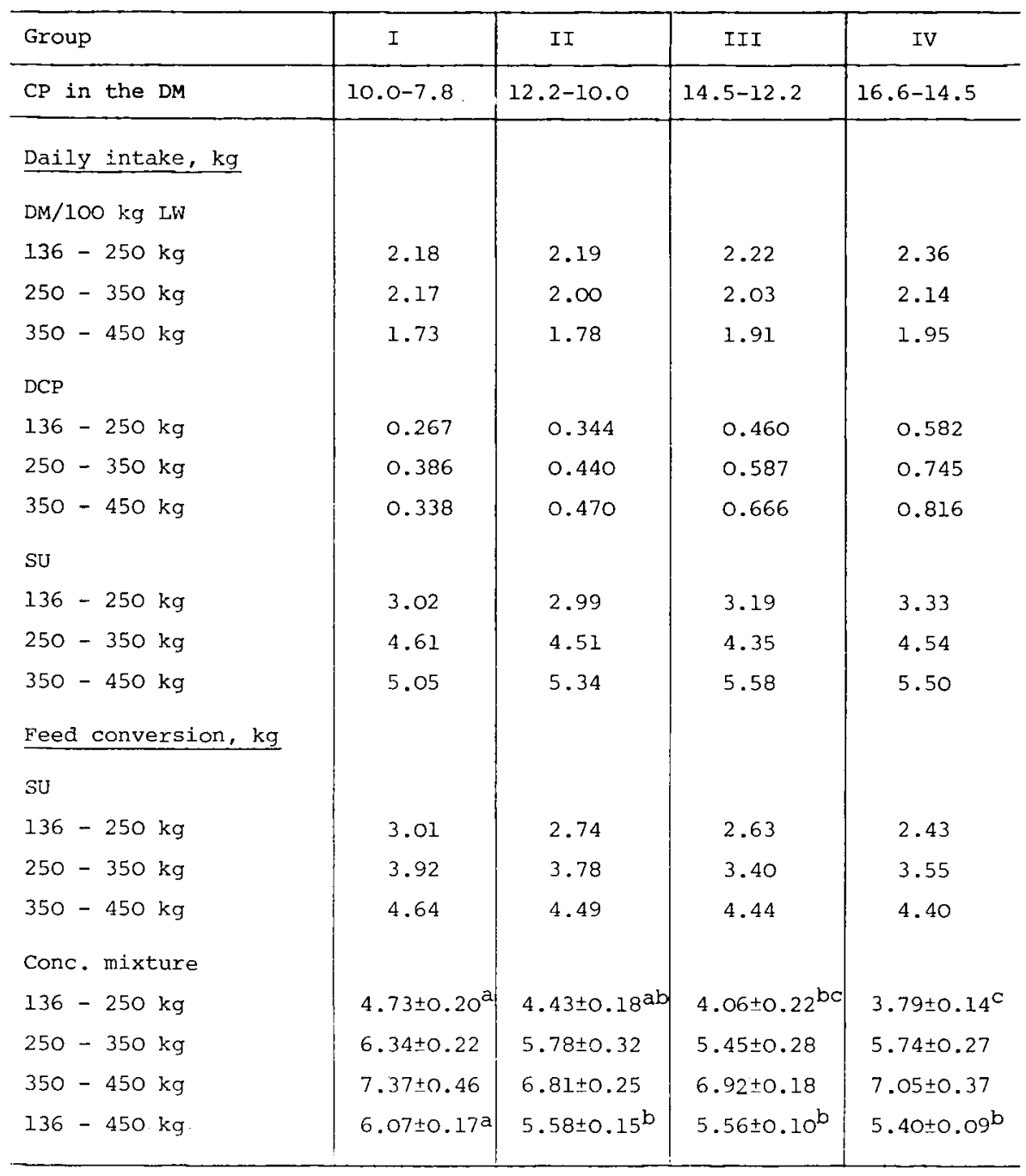

$a, b, c_{\text {Means with different superscripts are different. }}$

et al., 1970, 1971). The DCP intake in this experiment is consistently below Rostock's recommendations in groups I and II (JENTSCH et al., 1975). It met these recommendations in group III, and exceeded them in group IV, for the respective LW and LWG. The DCP intake of animals fed 14.5-12.2 per cent CP is close to NRC (1970) recommendations for steers weighing $250-400 \mathrm{~kg}$ and gaining $1.3 \mathrm{~kg} /$ day.

The feed conversion was most efficient in group IV, with the highest CP level in the DM of the ration. It gradually decreased by decreasing the protein 
level, but only significant difference was that between group I (10 - 7.8 per cent $\mathrm{CP}$ ) and the other three groups, which shows no benefit by feeding rations with a protein content less than 10 per cent, especially at the beginning of fattening, where it should be at least 12 per cent.

Buysse (1969), OBRAČEVIĆ et al. (1970, 1971, 1975) and ITCF (1976a, $1977 a$ ) found no significant differences in feed intake or feed conversion in bulls fattened on $\mathrm{HC}$ rations with higher $\mathrm{CP}$ levels in the $\mathrm{DM}$ ranging from 11.6 to 20.2 per cent. Williams et al. (1975) reported no difference in feed efficiency of bulls fed on rations containing 11 and 10 per cent, $C P$ in the final period of fattening but another ITCF(1976) report showed a detrimental effect of rations containing 12.1 - 10.3 per cent CP. EDWARDs et al. (1976) found significant differences in DM intake and feed conversion efficiency by decreasing CP content of the ration to 10 per cent comparing to 14 per cent of CP, while KAY observed the same tendency (1977) by changing the CP content from 14.5 or 12 per cent to 9.4 per cent. However, DE BOER and HAMM (1977) obtained from MRIJ and FH bulls the LWG of $1050-1250 \mathrm{~g}$ by using the concentrate mixture containing $101 \mathrm{~g}$ of $\mathrm{CP} / \mathrm{kg}$.

On the basis of these data it seems that for bulls up to $250 \mathrm{~kg}$ of $\mathrm{LW}$ for satisfactory LWG and feed efficiency the rations should contain at least 14 per cent CP in DM, while about 12 per cent CP would be sufficient up to $350 \mathrm{~kg}$, which could be lowered to 10 per cent in the final period of fattening.

\section{References}

Boer F., DE, HAMM G.G.H., 1977. Effect of various feed-protein-levels upon daily gain and carcass-quality of fattening bulls of FH and MRIJ breed. 28th Annual Meeting EAAP, Brussels.

BuYsSE F., 1969. Intensive beef production. VIIth International Congress of Nutrition. Prague, 1969.

EDWards I.E., SWAN H., 1976. Response of growing bulls to dietary nitrogen concentration. Proc. Br. Soc. Anim. Prod. 22, 143.

Giardini A., Gaspari F., 1976. Nitrogen sources in beef cattle diets. In "Improving the nutritional efficiency of beef production", EEC, Luxembourg.

Giardini A., Lambertini F., Gaspari F., Lo Bruno A., 1976a. Levels, sources and methods of nitrogen supplementation of maize silage for beef production. Anim. Feed. Sci. Tech. 1, No. 2-3.

ITCF, 1976. Maïs grain pour jeanes bovins Normands. Etude du niveau de complémentation azotée. Résumés des expériences et documents publiés en 1975, No. 2.

ITCF, 1976a. Mä̈s déshydraté pour jeunes bovins Montbéliards. Comparaison du tourteau de soja et de l'urée. Résumés des expériences et documents publiés en 1975. No. 2.

ITCF, 1977. Maïs plante entière ensilé pour jeunes bovins Normands. Etude du niveau de complementation azotée. Rapport, 1976.

ITCF, 1977a. Maïs grain pour jeunes bovins Charolais. Comparaison dune ration fermière à un aliment complet. Rapport 1976.

ITCF, 1978. Complémentation azotéc du maïs ensilage chez les jeanes bovins FFPN. Rapport 1977.

Jentsch W., Hoffmann L., Schiemann L.R., Wittenburg Hildegard, 1975. Die Verwertung der Futterenergie durch wachsende Bullen und die Ableitung prazisierter Energie und Proteinnormen. Tag.-Ber., Akad. Landwirtsch. .Wiss. DDR, Berlin, 133, s. 89-106.

KAY M., 1977. Intensive beef production systems. 28th Annual Meeting EAAP, Brussels.

Martin T.G., Perry T.W., Beeson W.M., Mohler M.T., 1978. Protein levels on bulls : Comparison of three continuous dietary levels on growth and carcass traits. J. Anim. Sci. 47, 1 . 
NRC, 1970. Nutrient Requirements of Domestic Animals. No. 4., Nutrient requirements of beef cattle. NRC-NAS, Washington, D.C.

Obračević Č., BaČVANSKI S., Čobić T., Vučetić Sofija 1970. The effect of different protein quantities in the concentrate rations of young fattening bulls fed at libitum. $J$. Sci. Agric. Res. 22, 76.

Obračević Č., Bačvanski S., Čobić T., Vučltić Sofija 1971. The effed of different levels of urea on nitrogen retention and feed efficiency in the fattening of young bulls with concentraes. J. Sci. Agric. Res. 23, 81.

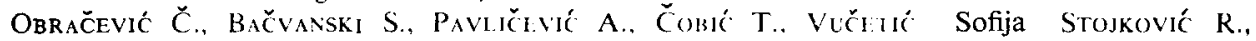
1975. Urea instead of protein concentrate in fattening young bulls, J. Sci Agric. Res. 28, 104.

SORENSEN M., KOUSciand K., 1977. Effect of protein content of feed on weight gain. carcass quality and meat quality of fattening calves and young bulls. From $N A R$, Series $\mathrm{B}$.. 47, 2, 819.

Williams D.B., VetTer R.I., Burroughs W., Tofei. D.G., 1975. Effects of ration protejin level and dicthylstilbestrol implants on early weaned beef bulls. J. Anim. Sci.. 41. 6. 